\title{
Impact of Kishnica and Badovci Flotation Tailing Dams on Levels of Heavy Metals in Water of Graçanica River (Kosovo)
}

\author{
Fatbardh Gashi, ${ }^{1}$ Stanislav Frančišković-Bilinski, ${ }^{2}$ Halka Bilinski, ${ }^{2}$ \\ Agron Shala, ${ }^{3}$ and Anilë Gashi ${ }^{1}$ \\ ${ }^{1}$ Department of Chemistry, Faculty of Natural Sciences, University of Prishtina, Prishtina, Kosovo \\ ${ }^{2}$ Institute "Ruđer Bošković", Division for Marine and Environmental Research, 10002 Zagreb, Croatia \\ ${ }^{3}$ Hydrometeorological Institute, 10000 Prishtina, Kosovo \\ Correspondence should be addressed to Stanislav Frančišković-Bilinski; francis@irb.hr
}

Received 15 November 2016; Accepted 18 January 2017; Published 19 February 2017

Academic Editor: Henryk Kozlowski

Copyright (C) 2017 Fatbardh Gashi et al. This is an open access article distributed under the Creative Commons Attribution License, which permits unrestricted use, distribution, and reproduction in any medium, provided the original work is properly cited.

\begin{abstract}
The main objective of this study was to perform assessment of water quality of Graçanica River (Kosovo), impacted by Kishnica and Badovci flotation tailing dams, using ICP-OES method. The obtained results show that the mean values of all heavy metals in studied river water samples were significantly high, with following maximal concentrations: As $\left(0.033 \mathrm{mgL}^{-1}\right), \mathrm{Cd}\left(0.002 \mathrm{mgL}^{-1}\right), \mathrm{Cr}^{-1}$ (0.225 mgL $\left.\mathrm{m}^{-1}\right), \mathrm{Cu}\left(0.015 \mathrm{mgL}^{-1}\right), \mathrm{Hg}\left(0.004 \mathrm{mgL}^{-1}\right), \mathrm{Mn}\left(15.66 \mathrm{mgL}^{-1}\right), \mathrm{Ni}\left(0.255 \mathrm{mgL}^{-1}\right), \mathrm{Pb}\left(0.013 \mathrm{mgL}^{-1}\right)$, and $\mathrm{Zn}\left(0.612 \mathrm{mgL}^{-1}\right)$, but only two samples from locations influenced by Kishnica and Badovci flotation tailing dams showed statistically anomalous values of $\mathrm{Cr}^{3+}, \mathrm{Cu}^{2+}, \mathrm{Mn}^{2+}, \mathrm{Zn}^{2+}$, and $\mathrm{Hg}^{2+}$. According to assessment based on Croatian standards, locations near both flotation tailing dams are significantly polluted with majority of studied metals, while downstream sampling stations are almost unpolluted or slightly polluted. Mercury is found to be the most significant contaminant. According to WHO recommended values for drinking water, on all locations values were within the limits for $\mathrm{Al}, \mathrm{Cd}, \mathrm{Cu}$, and $\mathrm{Zn}$, while for $\mathrm{As}, \mathrm{Cr}, \mathrm{Hg}, \mathrm{Mn}, \mathrm{Ni}$, and $\mathrm{Pb}$ values exceed recommended values on some sampling stations. Further monitoring of water and possibly sediments of Graçanica River is advised, as well as performing of remediation of Kishnica and Badovci mine tailing dams.
\end{abstract}

\section{Introduction}

Today heavy metals (Cd, $\mathrm{Cu}, \mathrm{Zn}, \mathrm{Cr}, \mathrm{Hg}, \mathrm{Mn}, \mathrm{Ni}, \mathrm{Pb}$, etc.) are significant environmental pollutants, and every day their dangers and toxicity for biosphere are increasing [1]. Many heavy metals are distributed in soil and natural waters and smaller amounts are present in atmosphere as particulate or vapors. Some of these heavy metals like $\mathrm{Cu}$ and $\mathrm{Zn}$ are essential elements to life as cofactor and activators of enzyme reactions [2]. Mining and mining activities are source of metal contamination of life systems and could have an impact on the environment and life system and can cause associated diseases [3-5]. Mining activities generate waste rocks and concentrator tailings without any environmental and life protection $[6,7]$.

Animal activities on contaminated plants and using heavy metal polluted waters accumulate heavy metals in their tissues and milk. Heavy metals are easily passing from polluted surface waters to ground water [8-10]. Drinking water gradually became scarce commodity, due to mixing up of huge contaminants through natural process like soil and rock weathering and anthropogenic activities [11, 12]. Metallic elements are environmentally stable and can enter living system through polluted water, soil, and air and can accumulate up to extended period, resulting in acute adverse effects on life system. Metals in natural waters allocate between dissolved species and species bound to particular (colloid) particles and for better understanding of cycling of trace metals processes it is necessary to know their distribution and their particular concentration of species [13-15]. Frank Riesbeck elaborated the most environmental hazards associated with the tailings impoundment, with or without restart of the work of concentrator's in Leposaviq and Kishnica 
(http://www.ks.undp.org/content/dam/kosovo/docs/TrepcaConf/TREPCA\%20Conf\%20Report_Engl.pdf). The author considers that contamination of groundwater beneath of the impoundment by metals leaches from the tailings, contamination of sediments and surface water from tailings materials, eroding from the faces of the tailings impoundments and from the contaminated agricultural soil [16]. To assess the water quality of a water body, four main approaches can be used: water quality index, trophic status index, statistical analysis of the water quality data such as correlation analysis, and biological analysis [17]. Multivariate statistical methods, such cluster and discriminant analysis, have been proved to be one of the most useful tools for extracting meaningful information from data sets [18-21]. Unfortunately none of the mentioned multivariate statistical methods was applicable to our data. The main reason for that is small number of samples (cases). As a rule, number of used variables in such multivariate statistical study should not exceed number of samples (cases). Using of only $<6$ variables in such multivariate analysis would make results not reasonable, so we decided not to apply those methods in the current study.

This study about river water quality is a continuation of studies [22-27] on quality of the surface and ground waters in Kosovo. In Kishnica district there are huge flotation deposits, accumulated from flotation process of minerals from mine of Kishnica, Hajvalija, Badovci, and Artana. This area is rich in natural resources, important for the economic development of Kosovo. The Kishnica mine location and its industrial potential represent an area of potential pollution and can be considered as environmental hotspot. This site is polluted by numerous tailings, scattered irregularly and without any measure to prevent environment damage [28]. In 2012 a project entitled "Clean-Up of Graqanka River Bed in Lapje Sella Village of Graçanica Municipality" implemented in the framework of "EU-Beautiful Kosovo Programme" (http://www.kosovoprojects.eu/en/content/clean-gracankariver-bed-lapje-selllaplje-selo-village-gracanicegracanicamunicipality) was performed, in order to rehabilitate the river bed. Unfortunately this project did not study pollution chemistry of water or sediments. The river of Graçanica is located near the deposited flotation tailings (total area from 40 ha with average height of $20 \mathrm{~m}$ is disposed $5.9 \mathrm{mil} \cdot \mathrm{m}^{3}$ of tailings) in Kishnica and Badovci villages [29]. Further, the objective of this study is to know the influence of flotation activity on the concentration of heavy metals in river water of Graçanica.

\section{Study Area and Sampling}

The Graçanica is a river originating from Gollaku Mountain about $19 \mathrm{~km}$ long left bank tributary to the Sitnica River. The river originally flows to the west and receives many streams coming down from Badovci, Kishnica, and Hajvalija villages. The composite valley of the river is densely populated, with several large villages (Badovci, Kishnica, Graçanica, Hajvalija, Laplje Selo, Preoci, Lepia, Dobreva e ulët, and Vragolia). Near the village of Vragolia, the Graçanica River splits and empties into the Sitnica River.

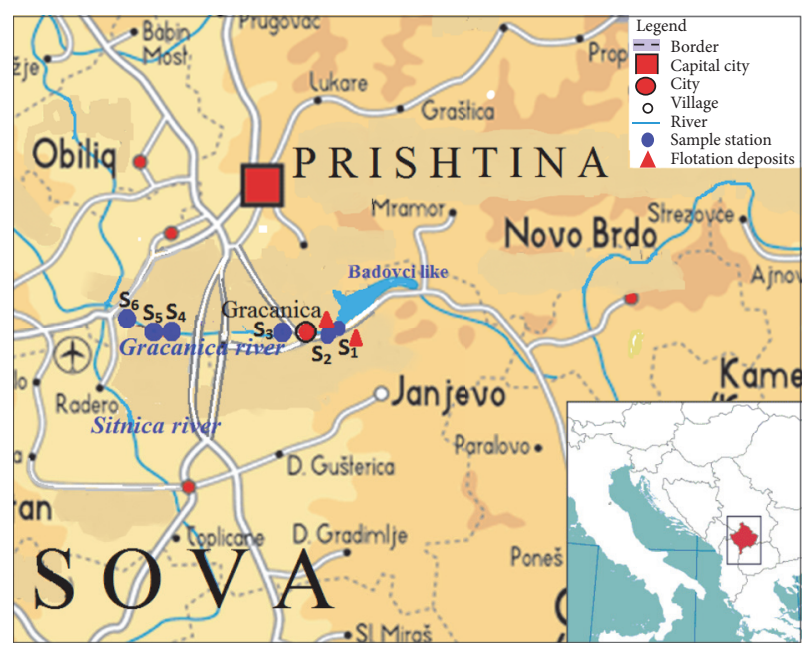

FIGURE 1: Study area, sampling stations, and flotation tailings.

Sampling of water samples was performed at 12 may 2014 and the sampling network was established in order to cover the river spatially, taking into account anthropogenic pressures on the river. Geographic coordinates were determined using GPS device Extras, "GARMIN, 12 channel" and locations were well described. Portable instruments were used to measure water temperature, electrical conductivity, $\mathrm{pH}$, and total dissolved solids. Water samples were collected in polyethylene bottles (bottles were rinsed with lake's water). Water samples were collected for analysis according to the recommended procedures [30-32]. A quantity of each water sample was extracted and filtrated to determinate turbidity, alkalinity, total hardness, and so forth. Rest of water samples were preserved according to standard procedures [33-35]. The study area with the sampling stations is presented in Figure 1 and the details about sampling sites are presented in Table 1.

\section{Materials and Methods}

3.1. Determination of Physicochemical Parameters. Water temperature, $\mathrm{pH}, \mathrm{EC}$, and TDS were performed immediately after sampling using pH-meter, model "Hanna Instruments, $\mathrm{pH} \&$ EC." Determination of the turbidity was performed using "HACH 2100P ISO Turbidimeter." Total hardness was determined by EDTA volumetric titration. Chemical consumption of $\mathrm{KMnO}_{4}$ was determined by Thiemann Küebel volumetric method.

3.2. Determination of Heavy Metals by ICP-OES. Determination of the concentrations of heavy elements is difficult and the results obtained often vary according to the chosen analytical technique. Inductively Coupled Plasma Optical Emission Spectroscopy (ICP-OES) is the detection of the light emitted by the elements in a sample introduced into an ICP source. The measured emission intensities are then compared to the intensities of standards of known concentration to obtain the elemental concentrations in 
TABLE 1: Sampling stations with detailed locality description.

\begin{tabular}{lcccl}
\hline Sample & Locality & Coordinates & Height over sea/m & Possible pollution sources \\
\hline $\mathrm{S}_{1}$ & Badovci village & 34T 0518011 UTH 4717511 & 613.0 & $\begin{array}{l}\text { Mining from Hajvalia and Badovci, } \\
\text { traffic }\end{array}$ \\
$\mathrm{S}_{2}$ & Kishnica village & 34T 0517393 UTH 4716752 & 606.0 & $\begin{array}{l}\text { Flotation deposits of Kishnica and } \\
\text { Badovci pollution from peripheral } \\
\text { rivers, settlement, traffic } \\
\text { Flotation deposits of Kishnica and }\end{array}$ \\
$\mathrm{S}_{3}$ & Graçanica city & 34T 0514789 UTH 4716420 & 591.3 & $\begin{array}{l}\text { Badovci, waste waters from } \\
\text { Graçanica, agricultural }\end{array}$ \\
$\mathrm{S}_{4}$ & Miradi e epërme village & 34T 0507132 UTH 4716509 & 556.3 & $\begin{array}{l}\text { Settlement and agriculture } \\
\text { Waste waters from Miradia village, } \\
\text { milk factory "Bylmeti," agriculture }\end{array}$ \\
$\mathrm{S}_{5}$ & Miradi e epërme village & 34T 0507129 UTH 4716508 & 552.0 & $\begin{array}{l}\text { Waste waters from Miradia village, } \\
\text { agriculture, traffic }\end{array}$ \\
\hline $\mathrm{S}_{6}$ & Vragolia village & 34T 0505536 UTH 4717629 & 547.0 & \\
\hline
\end{tabular}

TABLE 2: Some physicochemical parameters determined in river water.

\begin{tabular}{|c|c|c|c|c|c|c|c|}
\hline Sample & W. T. $/{ }^{\circ} \mathrm{C}$ & $\mathrm{pH} / 1$ & Turb./NTU & $\mathrm{EC}, / \mu \mathrm{Scm}^{-1}$ & $\mathrm{TDS} / \mathrm{mgL}^{-1}$ & Total H. $/^{\circ} \mathrm{dH}$ & Cons. of $\mathrm{KMnO}_{4} / \mathrm{mgL}^{-1}$ \\
\hline $\mathrm{S}_{1}$ & 17.7 & 6.82 & 19.3 & 1199 & 16.5 & 35.24 & 74.33 \\
\hline $\mathrm{S}_{2}$ & 20.6 & 6.14 & 31.1 & 3020 & 53 & 95.39 & 46.45 \\
\hline $\mathrm{S}_{3}$ & 16.2 & 6.16 & 8.6 & 2169 & 51 & 67.47 & 78.67 \\
\hline $\mathrm{S}_{4}$ & 14.9 & 6.26 & 20.7 & 1173 & 6.5 & 30.04 & 59.98 \\
\hline $\mathrm{S}_{5}$ & 15.8 & 6.32 & 8.4 & 1201 & 13.4 & 33.43 & 43.44 \\
\hline $\mathrm{S}_{6}$ & 16.4 & 6.87 & 8.9 & 1184 & 10.6 & 32.24 & 66.02 \\
\hline
\end{tabular}

the unknown sample. Chemical analysis of heavy metals in river water was performed in commercial laboratory "Agrovet” using Perkin Elmer "Optima 2100 DV ICP Optical Emission Spectrometer." Limits of detection (LOD) of some metals were as follows: $\mathrm{Al}\left(0.001 \mathrm{mgL}^{-1}\right)$, As $\left(0.002 \mathrm{mgL}^{-1}\right)$, $\mathrm{Hg}\left(0.001 \mathrm{mgL}^{-1}\right), \mathrm{Cd}\left(0.0001 \mathrm{mgL}^{-1}\right), \mathrm{Pb}\left(0.001 \mathrm{mgL}^{-1}\right), \mathrm{Cr}$ $\left(0.0002 \mathrm{mgL}^{-1}\right), \mathrm{Mn}\left(0.0001 \mathrm{mgL}^{-1}\right), \mathrm{Cu}\left(0.0004 \mathrm{mgL}^{-1}\right), \mathrm{Zn}$ $\left(0.0002 \mathrm{mgL}^{-1}\right)$, and $\mathrm{Ni}\left(0.0005 \mathrm{mgL}^{-1}\right)$.

3.3. Statistical Methods. Software Statistica 6.0 [36] was used for the statistical approach in this work, such as descriptive statistics, Pearson's correlation factor and two-dimensional box plot diagrams for determination of anomalies (extremes and outliers) for solution data. Relationships between the observed variables were tested by means of correlation analysis. The level of significance was set at $p<0.05$ for all statistical analyses. It was qualitatively assumed that the absolute values of $r$ between 0.3 and 0.7 indicate good association, and those between 0.7 and 1.0 strong association between elements.

\section{Results and Discussion}

4.1. Physicochemical Parameters. In Table 2 are presented values of some physicochemical parameters determined in river water samples of Graçanica.

Water temperature varied at different locations and ranged from 14.9 to $20.6^{\circ} \mathrm{C}$, what might be due to the rate of chemical reactions and the nature of biological processes taking place in aquatic system. The $\mathrm{pH}$ affects chemical and biological processes and temperature affects the availability of oxygen concentration in the water. Based on $\mathrm{pH}$ measurements, the river water is slightly acidic with values ranging from 6.14 to 6.87 , what is much lower than the values found in karstic rivers of Croatia ( $\mathrm{pH}$ up to 8.7) [37]. The lower $\mathrm{pH}$ at stations $\mathrm{S}_{2}, \mathrm{~S}_{3}$, and $\mathrm{S}_{4}$ may be due to the dissolution and decomposition of sulfide minerals including metal sulfides deposited in flotation tailings in Kishnica. Mean values of EC values are relatively high in the whole course of Graçanica River and were about three times higher than values measured in karstic Kupa and Rječina Rivers (Croatia) [37]. These values are above highest desirable World Health Organization limit $\left(1000 \mu \mathrm{scm}^{-1}\right)$. There is an influence of pollution from mining activities from Hajvalija and Kishnica mines and from deposits of the flotation tailings of Kishnica and Badovci. Going downstream EC values are gradually decreasing to the lowest value of $1184 \mu \mathrm{Scm}^{-1}$, which is measured at station $\mathrm{S}_{6}$ near the confluence of Graçanica with Sitnica River. TDS give information on the total cations and anions in waters, which are also a possible sign of anthropogenic influence. The effluent draining and mine wastes contained elevated levels of those ions. TDS values (behave similarly as EC) of all water samples ranged from 1.6 to $53 \mathrm{mgL}^{-1}$. Turbidity ranged from 8.4 to $31.1 \mathrm{NTU}$ (what is not in agreement with the WHO standards) due to influence from deposited flotation tailings in Kishnica and waste waters from milk factory "Bylmeti." Values of total hardness depend upon dissolved salts present in water. They are very high and are ranged $30.04-95.39^{\circ} \mathrm{dH}$, as influenced from deposited flotation tailings in Kishnica. Chemical consumption of $\mathrm{KMnO}_{4}$ ranged from 43.44 to 
TABLE 3: Concentration of 10 metals determined in river water.

\begin{tabular}{|c|c|c|c|c|c|c|c|}
\hline \multirow{2}{*}{ Heavy metals } & \multicolumn{7}{|c|}{ Sample } \\
\hline & $\mathrm{S}_{1}$ & $\mathrm{~S}_{2}$ & $\mathrm{~S}_{3}$ & $\mathrm{~S}_{4}$ & $\mathrm{~S}_{5}$ & $\mathrm{~S}_{6}$ & WHO standard \\
\hline $\mathrm{Al} / \mathrm{mgL}^{-1}$ & $<0.001$ & $<0.001$ & $<0.001$ & $<0.001$ & $<0.001$ & $<0.001$ & 0.2 \\
\hline As $/ \mathrm{mgL}^{-1}$ & 0.033 & 0.001 & 0.013 & 0.029 & 0.027 & 0.026 & 0.01 \\
\hline $\mathrm{Cd} / \mathrm{mgL}^{-1}$ & 0.001 & 0.002 & $<0.0001$ & 0.001 & $<0.0001$ & $<0.0001$ & 0.003 \\
\hline $\mathrm{Cr} / \mathrm{mgL}^{-1}$ & 0.225 & 0.037 & 0.010 & 0.007 & 0.007 & 0.007 & 0.05 \\
\hline $\mathrm{Cu} / \mathrm{mgL}^{-1}$ & 0.015 & 0.002 & 0.001 & 0.002 & 0.002 & 0.001 & 2 \\
\hline $\mathrm{Hg} / \mathrm{mgL}^{-1}$ & $<0.001$ & 0.004 & 0.002 & $<0.001$ & 0.001 & 0.002 & 0.001 \\
\hline $\mathrm{Mn} / \mathrm{mgL}^{-1}$ & 0.027 & 15.66 & 1.98 & 0.018 & 0.001 & 0.001 & 0.5 \\
\hline $\mathrm{Ni} / \mathrm{mgL}^{-1}$ & 0.196 & 0.255 & 0.118 & 0.006 & 0.003 & 0.007 & 0.02 \\
\hline $\mathrm{Pb} / \mathrm{mgL}^{-1}$ & 0.002 & 0.010 & 0.003 & 0.013 & 0.006 & 0.005 & 0.01 \\
\hline $\mathrm{Zn} / \mathrm{mgL}^{-1}$ & $<0.0002$ & 0.612 & 0.159 & 0.009 & 0.011 & 0.002 & 3 \\
\hline
\end{tabular}

TABLE 4: Descriptive statistics of the 9 variables in 6 cases.

\begin{tabular}{|c|c|c|c|c|c|c|c|}
\hline \multirow{2}{*}{ Variable } & \multicolumn{7}{|c|}{ Descriptive statistics } \\
\hline & Mean & Geometric & Median & Minimum & Maximum & Variance & Std. dev. \\
\hline As/mgL ${ }^{-1}$ & 0.022 & 0.014 & 0.027 & 0.001 & 0.033 & 0 & 0.012 \\
\hline $\mathrm{Cd} / \mathrm{mgL}^{-1}$ & 0.001 & 0 & 0.001 & 0 & 0.002 & 0 & 0.001 \\
\hline $\mathrm{Cr} / \mathrm{mgL}^{-1}$ & 0.049 & 0.017 & 0.009 & 0.007 & 0.225 & 0.008 & 0.087 \\
\hline $\mathrm{Cu} / \mathrm{mgL}^{-1}$ & 0.004 & 0.002 & 0.002 & 0.001 & 0.015 & 0 & 0.005 \\
\hline $\mathrm{Hg} / \mathrm{mgL}^{-1}$ & 0.002 & 0.002 & 0.002 & 0.001 & 0.004 & 0 & 0.001 \\
\hline $\mathrm{Mn} / \mathrm{mgL}^{-1}$ & 2.948 & 0.050 & 0.023 & 0.001 & 15.660 & 39.404 & 6.277 \\
\hline $\mathrm{Ni} / \mathrm{mgL}^{-1}$ & 0.098 & 0.030 & 0.063 & 0.003 & 0.255 & 0.012 & 0.110 \\
\hline $\mathrm{Pb} / \mathrm{mgL}^{-1}$ & 0.007 & 0.005 & 0.006 & 0.002 & 0.013 & 0 & 0.004 \\
\hline $\mathrm{Zn} / \mathrm{mgL}^{-1}$ & 0.132 & 0.013 & 0.010 & 0 & 0.612 & 0.059 & 0.243 \\
\hline
\end{tabular}

$78.67 \mathrm{mgL}^{-1}$, and these values exceed WHO highest desirable limit from $10 \mathrm{mgL}^{-1}$. Those higher values of consumption of $\mathrm{KMnO}_{4}$ might be sign of anthropogenic environmental pollution as influence from deposited flotation tailings in Kishnica, waste waters from Graçanica city, and waste waters from milk factory.

4.2. Distribution of Heavy Metals and Their Mutual Correlations. In Table 3 are presented concentrations of 10 heavy metals $\left(\mathrm{mgL}^{-1}\right)$ in water of Graçanica River in comparison with WHO standards for drinking waters. The descriptive statistics summary of the selected variables of water samples are presented in Table 4 . For each variable, the values are given as arithmetic mean, geometric mean, median, minimal, and maximal concentration, variance, and standard deviation. Scatter box plot diagrams for measured variables are presented in Figure 2. Using experimental data from Table 3, obtained by ICP-OES method and box plot approach [38], anomalous values (extremes and outliers) of 8 heavy metals were determined (Table 5).

Only two samples $\left(S_{1}\right.$ and $\left.S_{2}\right)$ showed anomalous values. In sample $\mathrm{S}_{1}$ extremes of $\mathrm{Cr}^{3+}\left(0.225 \mathrm{mgL}^{-1}\right)$ and of $\mathrm{Cu}^{2+}$ $\left(0.015 \mathrm{mgL}^{-1}\right)$ were registered, while in sample $\mathrm{S}_{2}$ extreme of $\mathrm{Mn}^{2+}\left(15.66 \mathrm{mgL}^{-1}\right)$ and outliers of $\mathrm{Zn}^{2+}\left(0.612 \mathrm{mgL}^{-1}\right)$ and $\mathrm{Hg}^{2+}\left(0.004 \mathrm{mgL}^{-1}\right)$ were registered. Anomalies are caused by Kishnica and Badovci flotation tailing deposits.
TABLE 5: Water samples with anomalous values (extremes and outliers) of heavy metals.

\begin{tabular}{lcc}
\hline Sample & $\begin{array}{c}\text { Extremes of } \\
\text { parameters }(\mathrm{o})\end{array}$ & \multicolumn{1}{c}{$\begin{array}{c}\text { Outliers of } \\
\text { parameters }(\mathrm{a})\end{array}$} \\
\hline $\mathrm{S}_{1}$ & $\begin{array}{c}\mathrm{Cr}^{3+}\left(0.225 \mathrm{~mL}^{-1}\right), \\
\mathrm{Cu}^{2+}\left(0.015 \mathrm{mLL}^{-1}\right)\end{array}$ & No reg. \\
$\mathrm{S}_{2}$ & $\mathrm{Mn}^{2+}\left(15.66 \mathrm{mgL}^{-1}\right)$ & $\mathrm{Zn}^{2+}\left(0.612 \mathrm{mgL}^{-1}\right)$, \\
$\mathrm{S}_{3}$ & No reg. & $\mathrm{Hg}^{2+}\left(0.004 \mathrm{mgL}^{-1}\right)$ \\
$\mathrm{S}_{4}$ & No reg. & No reg. \\
$\mathrm{S}_{5}$ & No reg. & No reg. \\
$\mathrm{S}_{6}$ & No reg. & No reg. \\
& & No reg. \\
\hline
\end{tabular}

Correlation Pearson's factor for 9 variables was calculated to see if some of heavy metals were interrelated with each other and the results are presented in Table 6. The statistical regression analysis has been found a highly useful technique for the linear correlating between various water parameters. The correlation coefficient indicates positive and negative significant correlation of variables with each other. Positive correlation means that one parameter increases with other parameters and negative correlation means that one parameter increases with other parameters decrease. Arsenic showed moderate to strong positive relationship with $\mathrm{Cr}$ and $\mathrm{Cu}$. Cadmium showed very strong positive relationship with 

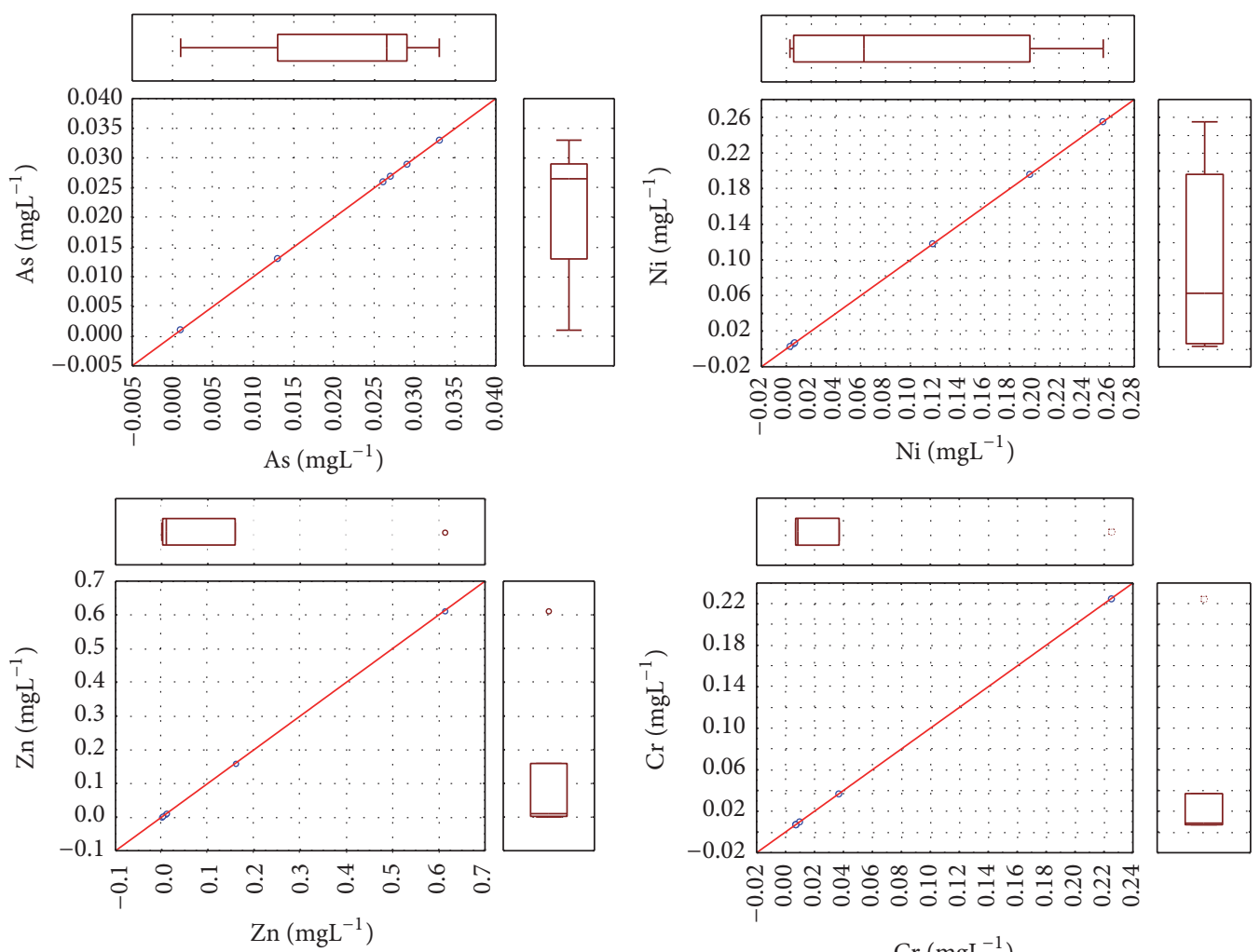

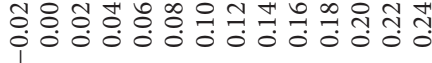

$\mathrm{Cr}\left(\mathrm{mgL}^{-1}\right)$
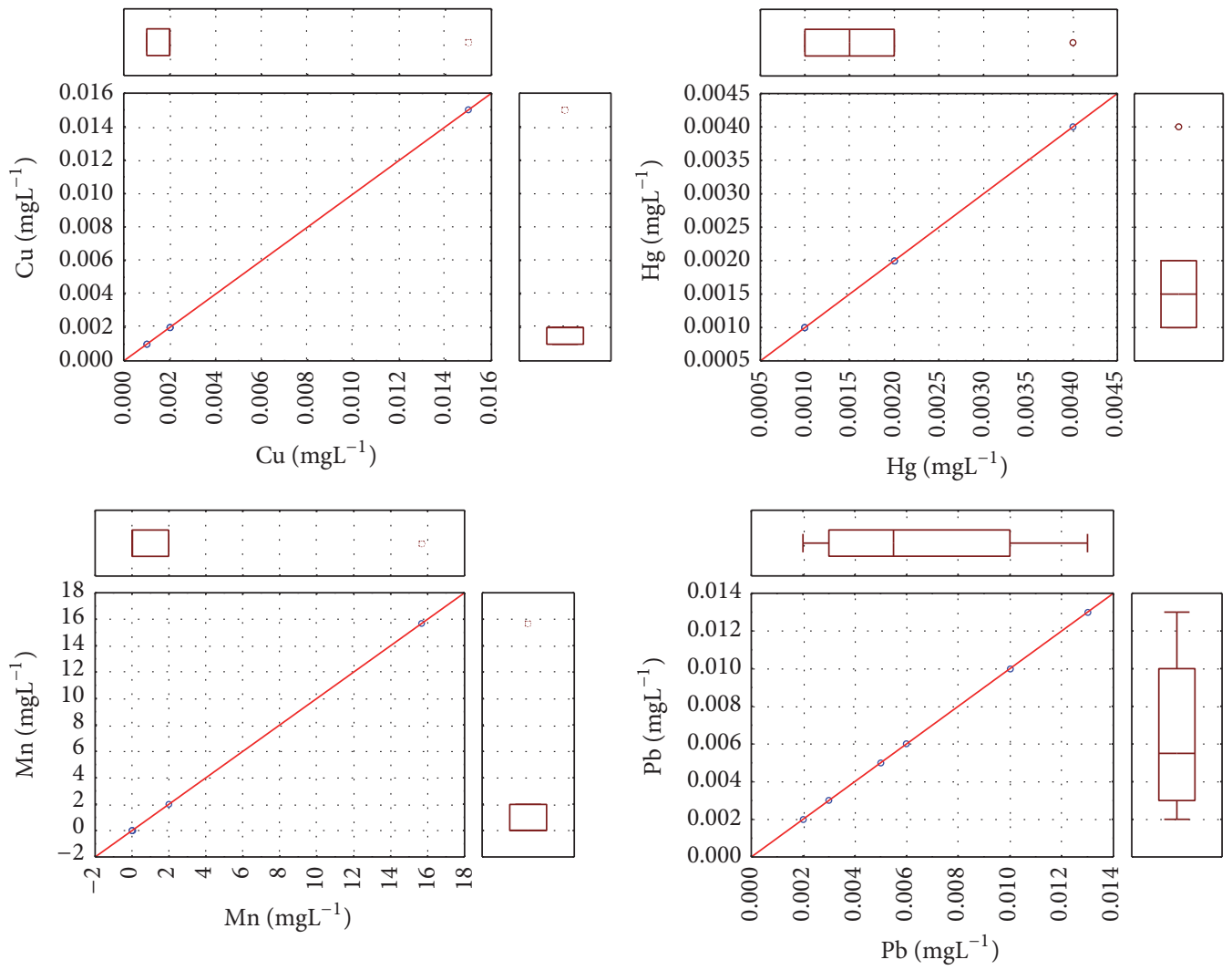

FIgURE 2: Scatter box plot diagrams of 8 selected heavy metals $\left(\mathrm{mgL}^{-1}\right)$. 
TABLE 6: Matrix of correlation coefficients $(r)$ of selected 9 variables.

\begin{tabular}{|c|c|c|c|c|c|c|c|c|c|}
\hline \multirow{2}{*}{ Variable } & \multicolumn{8}{|c|}{ Correlations, marked correlations are significant at $p<0.05000 \mathrm{~N}=6$} & \multirow[b]{2}{*}{$\mathrm{Zn}$} \\
\hline & As & $\mathrm{Cd}$ & $\mathrm{Cr}$ & $\mathrm{Cu}$ & $\mathrm{Hg}$ & $\mathrm{Mn}$ & $\mathrm{Ni}$ & $\mathrm{Pb}$ & \\
\hline As & 1.00 & & & & & & & & \\
\hline $\mathrm{Cd}$ & -0.47 & 1.00 & & & & & & & \\
\hline $\mathrm{Cr}$ & 0.35 & 0.29 & 1.00 & & & & & & \\
\hline $\mathrm{Cu}$ & 0.46 & 0.23 & 0.99 & 1.00 & & & & & \\
\hline $\mathrm{Hg}$ & -0.93 & 0.58 & -0.23 & -0.35 & 1.00 & & & & \\
\hline $\mathrm{Mn}$ & -0.89 & 0.78 & -0.09 & -0.20 & 0.93 & 1.00 & & & \\
\hline $\mathrm{Ni}$ & -0.58 & 0.72 & 0.55 & 0.45 & 0.63 & 0.73 & 1.00 & & \\
\hline $\mathrm{Pb}$ & -0.21 & 0.52 & -0.48 & -0.46 & 0.22 & 0.36 & -0.16 & 1.00 & \\
\hline $\mathrm{Zn}$ & -0.94 & 0.73 & -0.14 & -0.24 & 0.94 & 0.99 & 0.73 & 0.32 & 1.00 \\
\hline
\end{tabular}

$\mathrm{Mn}, \mathrm{Ni}$, and $\mathrm{Zn}$ and strong positive relationship with $\mathrm{Hg}$ and $\mathrm{Pb}$. Chromium showed very strong positive relationship with $\mathrm{Cu}$ and strong relationship with Ni. Copper showed strong positive relationship with Ni. Mercury showed very strong positive relationship with $\mathrm{Mn}$ and $\mathrm{Zn}$ and strong relationship with Ni. Manganese showed very strong positive relationship with $\mathrm{Ni}$ and $\mathrm{Zn}$ and moderate relationship with $\mathrm{Pb}$. Nickel showed very strong positive relationship with $\mathrm{Zn}$. Lead showed moderate positive relationship with $\mathrm{Zn}$. Mentioned relationships are indicating origin of those elements from ore waste after flotation of $\mathrm{Pb}$ and $\mathrm{Zn}$ ores, which was disposed in Kishnica and Badovci flotation tailing dams.

4.3. Assessment of Water Quality of Graçanica River. Classification of river water at each sampling location, based on concentrations of toxic metals, was performed using available standards from Croatian legislation (Narodne Novine 107/95 1998). According to mentioned legislation, water quality is determined for following 7 metals: $\mathrm{Cu}, \mathrm{Zn}, \mathrm{Cd}, \mathrm{Cr}, \mathrm{Ni}, \mathrm{Pb}$, and $\mathrm{Hg}$. All of them have been studied in the current paper and will be discussed. According to Croatian legislation, water is divided into 5 categories estimating toxicological influence on living communities of water bodies:

(I) No anthropogenic contamination with metals exists.

(II) Concentrations are not significantly higher than natural levels.

(III) Concentrations are lower than permanent toxic level.

(IV) Concentrations are periodically above permanent toxic level, but they do not cause permanent toxic conditions.

(V) Concentrations are above the permanent toxic level and are causing permanent (acute) toxic conditions.

According to concentrations of copper $(\mathrm{Cu})$, water on all studied locations belongs to (I) category $\left(<2 \mu \mathrm{gL}^{-1}\right)$, except on location $S_{1}$, where it belongs to (III) category (10$\left.15 \mu \mathrm{gL}^{-1}\right)$.

According to concentrations of zinc $(\mathrm{Zn})$, water on majority of studied locations $\left(\mathrm{S}_{1}, \mathrm{~S}_{4}, \mathrm{~S}_{5}\right.$, and $\left.\mathrm{S}_{6}\right)$ belongs to (I) category $\left(<50 \mu \mathrm{gL}^{-1}\right)$, on one location $\left(\mathrm{S}_{2}\right)$ it belongs to $(\mathrm{V})$ category $\left(>200 \mu \mathrm{gL}^{-1}\right)$, while on one location $\left(\mathrm{S}_{3}\right)$ it belongs to (IV) category $\left(100-200 \mu \mathrm{gL}^{-1}\right)$.

According to concentrations of cadmium (Cd), water on 3 studied locations $\left(\mathrm{S}_{3}, \mathrm{~S}_{5}\right.$, and $\left.\mathrm{S}_{6}\right)$ belongs to (I) category $\left(<0.1 \mu \mathrm{gL}^{-1}\right)$, while on 3 locations $\left(\mathrm{S}_{1}, \mathrm{~S}_{2}\right.$, and $\left.\mathrm{S}_{4}\right)$ it belongs to (III) category $\left(0.5-2.0 \mu \mathrm{gL}^{-1}\right)$.

According to concentrations of chromium (Cr), water on 4 studied locations $\left(\mathrm{S}_{3}, \mathrm{~S}_{4}, \mathrm{~S}_{5}\right.$, and $\left.\mathrm{S}_{6}\right)$ belongs to (III) category $\left(6-15 \mu \mathrm{gL}^{-1}\right)$, while on two locations $\left(S_{1}\right.$ and $\left.S_{2}\right)$ it belongs to (V) category $\left(>20 \mu \mathrm{gL}^{-1}\right)$.

According to concentrations of nickel $(\mathrm{Ni})$, water on 3 studied locations $\left(\mathrm{S}_{4}, \mathrm{~S}_{5}\right.$, and $\left.\mathrm{S}_{6}\right)$ belongs to (I) category $\left(<15 \mu \mathrm{gL}^{-1}\right)$, on 2 locations $\left(\mathrm{S}_{1}\right.$ and $\left.\mathrm{S}_{3}\right)$ it belongs to (IV) category (50-200 $\left.\mathrm{gL}^{-1}\right)$, and on one location $\left(\mathrm{S}_{2}\right)$ it belongs to $(\mathrm{V})$ category $\left(>200 \mu \mathrm{gL}^{-1}\right)$.

According to concentrations of lead $(\mathrm{Pb})$, water on one location $\left(\mathrm{S}_{1}\right)$ belongs to (II) category (0.1-2.0), on 2 locations $\left(\mathrm{S}_{3}\right.$ and $\left.\mathrm{S}_{6}\right)$ it belongs to (III) category $\left(2.0-5.0 \mu \mathrm{gL}^{-1}\right)$, while on 3 locations $\left(\mathrm{S}_{2}, \mathrm{~S}_{4}\right.$, and $\left.\mathrm{S}_{5}\right)$ it belongs to (IV) category (5.0$\left.80.0 \mu \mathrm{gL}^{-1}\right)$.

According to concentrations of mercury $(\mathrm{Hg})$, water on three studied locations $\left(\mathrm{S}_{2}, \mathrm{~S}_{3}\right.$, and $\left.\mathrm{S}_{6}\right)$ belongs to $(\mathrm{V})$ category $\left(>1.00 \mu \mathrm{gL}^{-1}\right)$ and on one location $\left(\mathrm{S}_{5}\right)$ it belongs to (IV) category $\left(0.10-1.00 \mu \mathrm{gL}^{-1}\right)$. On two locations $\left(\mathrm{S}_{1}\right.$ and $\left.\mathrm{S}_{4}\right)$ it is under detection limit $\left(0.001 \mathrm{mgL}^{-1}\right)$ and therefore it is hard to estimate whether it belongs to category (I), (II), (III), or (IV), due to limits of used ICP-OES method.

Chemical data from Table 3, scatter box plot diagrams (Figure 2), and World Health Organization standards for drinking water can be used for the assessment of water contamination by toxic heavy metals (As, $\mathrm{Cd}, \mathrm{Cr}, \mathrm{Cu}, \mathrm{Pb}$, $\mathrm{Zn}, \mathrm{Mn}, \mathrm{Al}, \mathrm{Ni}$, and $\mathrm{Hg}$ ). Heavy metal concentrations in natural waters are very low due to their low solubility in the aquatic environment. However, tens to hundreds of times these concentrations of the metals can be found in waters contaminated by various sources [39]. High concentrations of heavy metals which were found in river waters may be derived from interaction of rain with tailings containing elevated levels of these metals. Heavy metals from acidic 
tailings with sulfide minerals can be extracted by large amounts of rain, especially in the wet season. Thus, they can be continuously discharged downstream and decreased exponentially with distance from the tailings.

From the influence of deposited flotation tailings of Kishnica, Arsenic generally appeared to be significantly concentrated with maximum content of $0.029 \mathrm{mgL}^{-1}$ in sample $\mathrm{S}_{4}$. Samples $\mathrm{S}_{3}-\mathrm{S}_{6}$ exceed recommended standards for drinking water. The mercury generally appeared to be significantly concentrated in the river water in samples $S_{2}, S_{3}$, and $S_{6}$ as influence from deposited flotation tailings in Kishnica. The chromium appeared to be significantly concentrated in the samples $S_{1}$ and exceeds recommended WHO standards for drinking water as influenced from mining pollutants Hajvalija, Badovci, and Kishnica. The manganese appeared to be significantly concentrated in samples $S_{2}$ and $S_{3}$ as influence from deposited flotation tailings in Kishnica. The nickel appeared to be significantly concentrated in samples $S_{1}, S_{2}$, and $S_{3}$ as influenced from mining pollutants (Hajvalija, Badovci, and Kishnica) and deposited flotation tailings of Kishnica. The lead appeared to be significantly concentrated in all samples and exceed recommended WHO values. The lead appeared to be significantly concentrated in samples $S_{2}$ and $S_{3}$, as influence from mining pollutants and deposited flotation tailings in Kishnica. Decreasing of concentrations on some locations is caused by processes of adsorption, precipitation, and change of geologic setting. The concentration of aluminium in all samples of drinking water is under detection limit. The concentrations of cadmium and zinc were relativity high, but in all samples they were under recommended WHO norms for drinking water.

4.4. Assessment of Impact of the Kishnica and Badovci Flotation Tailing Dams and Other Pollution Sources on the Level of Heavy Metals in Water of Graçanica River. In Figure 3 is presented downstream spatial distribution of 8 heavy metals (As, $\mathrm{Hg}, \mathrm{Cd}, \mathrm{Pb}, \mathrm{Cr}, \mathrm{Mn}, \mathrm{Cu}$, and $\mathrm{Zn}$ ) in water of Graçanica River. From those graphical presentations, it can easily be observed that along Graçanica River there are two areas polluted with some of studied heavy metals. One of those pollution sources is located in the uppermost part of the river, around locations $S_{1}$ and $S_{2}$, while the other one is located around $S_{4}$ location in Miradi e epërme village. It is interesting that Kishnica and Badovci mine tailing dams pollute the river with different heavy metals. It could be observed that, at $S_{1}$ station, which is under the influence of Badovci mine tailing in river water are present high concentrations of As, $\mathrm{Cr}$, and $\mathrm{Cu}$ and slightly elevated concentrations of Cd. At $\mathrm{S}_{2}$ station, which is under the influence of Kishnica mine tailing, in river water are present high concentrations of $\mathrm{Hg}, \mathrm{Mn}, \mathrm{Zn}$, and $\mathrm{Cd}$ and in a less extent elevated concentrations of $\mathrm{Pb}$, which has its maximal concentration in the downstream part of the river, originating from other sources. From this it can be concluded that Badovci mine tailings significantly influence the quality of river water with $\mathrm{As}, \mathrm{Cr}$, and $\mathrm{Cu}$ and slightly with $\mathrm{Cd}$, while Kishnica mine tailings influence the quality with $\mathrm{Hg}, \mathrm{Mn}, \mathrm{Zn}, \mathrm{Cd}$, and $\mathrm{Pb}$.
Lead $(\mathrm{Pb})$ is behaving differently than majority of elements in Graçanica River, as its maximum is present at $\mathrm{S}_{4}$ location in Miradi e epërme village. This maximum originates from anthropogenic influence of Miradi e epërme village and possibly nearby main road. There is also a secondary maximum at $S_{2}$ station, whose origin is surely from Kishnica mine tailing.

Cadmium (Cd) also has two sources: the first one is from Kishnica and Badovci mine tailings, with maximal concentration at $S_{2}$ station. But there is a secondary maximum at location $S_{4}$ in Miradi e epërme village, whose origin is most probably anthropogenic.

Arsenic (As) behaves similarly as $\mathrm{Pb}$ and $\mathrm{Cd}$ : its first source originates from Badovci mine tailing and the secondary maximum is present at $\mathrm{S}_{4}$ location, whose origin is assumed to be anthropogenic. It is interesting that, unlikely for other investigated metals, elevated concentrations of As persist further downstream the river from $\mathrm{S}_{4}$ location, until its confluence with Sitnica River.

Graphical presentations from Figure 3 could indicate presence of strong self-purification mechanism in Graçanica River for most of investigated heavy metals, as concentrations of most of them drop to normal background levels on next sampling station going downstream. The same thing is happening both in the uppermost part of the river, influenced with mine tailings, and in the lower part with secondary maximum for some metals at $\mathrm{S}_{4}$ station, with the only exception of As, whose elevated concentrations persist downstream secondary maximum until the confluence with Sitnica River.

Our results will also be compared with results of [40], who investigated water and sediment at the abandoned $\mathrm{Pb}-\mathrm{Zn}$ mining site at Gyöngyösoroszi, Hungary, and its influence on the Toka Stream. This site was remediated and acidic mine drainages have been neutralized, but authors concluded that mine tailings still require continuous monitoring because under acidic to near neutral $\mathrm{pH}$ values, most of the dissolved potentially toxic elements are present in elevated concentrations. Downstream of the mine discharge, they found that, in the Toka Stream, Mn, Zn, Fe, and $\mathrm{Cd}$ were found in elevated concentrations at a location that was close to the discharge. At the same time, the abandoned mine tailing was found to be secondary contamination source, for example, the discharge of the tailing at Gyöngyösoroszi was found to contain high $\mathrm{Fe}, \mathrm{Mn}, \mathrm{Cd}$, $\mathrm{Zn}$, and $\mathrm{Al}$ concentrations and elevated $\mathrm{Ni}$ and $\mathrm{Cu}$ concentrations. When compared with concentrations found in Toka Stream [40], concentrations of all studied heavy metals in our research are significantly higher in Graçanica River. That is an indication that project "Clean-Up of Graçanka River Bed in Laplje Selo Village of Graçanica Municipality," implemented in the framework of "EU-Beautiful Kosovo Programme," performed in 2012 with the goal to "perform rehabilitation of the river bed creating beautified and healthier environment for the inhabitants" was not successful, as the project only performed cleaning of the river bed and did not pay attention to remediation of mine tailings of Kishnica and Badovci and to chemical pollution of river water. 

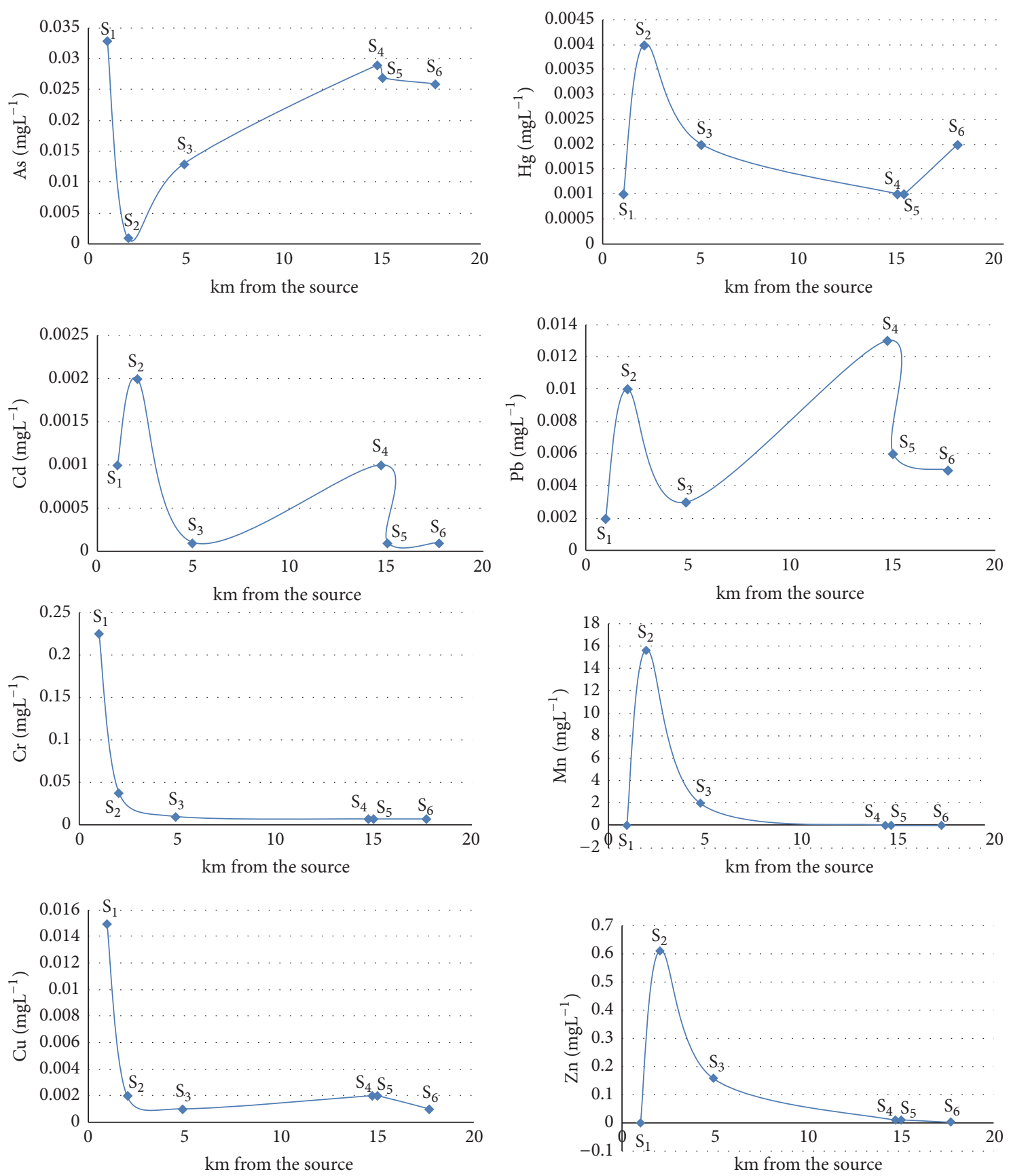

FIGURE 3: Downstream distribution of selected heavy metals in water of Graçanica River versus flow direction in km.

\section{Conclusions}

In this study, the distribution of 7 physicochemical parameters and 10 metals in water of Graçanica River were investigated. Most important findings were as follows:

(i) Generally, ground waters of Kosovo are enriched in dissolved solids, as the consequence of aquifer lithology and residence time of ground water. High values of some physicochemical parameters as EC, TDS turbidity, hardness, and consumption of $\mathrm{KMnO}_{4}$ showed a possible sign for significant pollution of river water as a result of mining activities, deposited flotation tailings in Kishnica and Badovci, wastewater from Graçanica city, and anthropogenic pollution in Miradia e ulët village.

(ii) Using experimental data obtained by ICP-OES method and box plot approach, anomalous values (extremes and outliers) of 8 heavy metals were determined. Only two samples $\left(S_{1}\right.$ and $\left.S_{2}\right)$ showed anomalous values. In sample $\mathrm{S}_{1}$ extremes of $\mathrm{Cr}^{3+}$ $\left(0.225 \mathrm{mgL}^{-1}\right)$ and of $\mathrm{Cu}^{2+}\left(0.015 \mathrm{mgL}^{-1}\right)$ were registered, while in sample $S_{2}$ extreme of $\mathrm{Mn}^{2+}$ 
$\left(15.66 \mathrm{mgL}^{-1}\right)$ and outliers of $\mathrm{Zn}^{2+}\left(0.612 \mathrm{mgL}^{-1}\right)$ and $\mathrm{Hg}^{2+}\left(0.004 \mathrm{mgL}^{-1}\right)$ were registered. Anomalies are caused by Kishnica and Badovci flotation tailing deposits.

(iii) The results for Pearson's correlation factors show very high positive relationship (correlation) between variables $\mathrm{Cd}$ and $\mathrm{Cr}, \mathrm{Cu}, \mathrm{Hg}, \mathrm{Mn}, \mathrm{Ni}, \mathrm{Pb}$, and $\mathrm{Zn}$. Mercury showed high significant positive relationship with $\mathrm{Mn}, \mathrm{Ni}, \mathrm{Pb}$, and $\mathrm{Zn}$, what could be a possible sign of influence from mining pollutants and deposited flotation tailings in Kishnica and Badovci.

(iv) Quality of river water was assessed based on concentrations of toxic metals, using available standards from Croatian legislation. According to mentioned legislation, water quality is determined for following 7 metals: $\mathrm{Cu}, \mathrm{Zn}, \mathrm{Cd}, \mathrm{Cr}, \mathrm{Ni}, \mathrm{Pb}$, and $\mathrm{Hg}$. According to most of those metals, locations $S_{1}$ and $S_{2}$ are significantly polluted, belonging to (IV) or (V) category of water quality, while downstream sampling stations are almost unpolluted or slightly polluted, belonging to (I), (II), or (III) category. Mercury is most significant contaminant present in Graçanica River, as big part of its flow belongs to $(\mathrm{V})$ category according to $\mathrm{Hg}$, what means that concentrations are above the permanent toxic level and are causing permanent (acute) toxic conditions.

(v) According to WHO recommended values for drinking water, Graçanica River water was on all locations within those limits for $\mathrm{Al}, \mathrm{Cd}, \mathrm{Cu}$, and $\mathrm{Zn}$. For following metals it exceeds recommended values: As on almost all locations, $\mathrm{Cr}$ on location $\mathrm{S}_{1}, \mathrm{Hg}$ on all locations except $S_{1}$ and $S_{4}, M n$ on locations $S_{2}$ and $S_{3}, \mathrm{Ni}$ on locations $S_{1}, S_{2}$, and $S_{3}$, and $\mathrm{Pb}$ on locations $\mathrm{S}_{2}$ and $\mathrm{S}_{4}$. Two main sources of pollution are identified along Graçanica River: One is around locations $S_{1}$ and $S_{2}$, which is influenced by Badovci and Kishnica mine tailing dams. The other source of pollution is around location $S_{4}$, which originates from different anthropogenic pollution from Miradi e epërme village.

(vi) When compared with concentrations found in Toka Stream [40], concentrations of all studied heavy metals in our research are significantly higher in Graçanica River, what is an indication that project implemented in the framework of "EU-Beautiful Kosovo Programme," performed in 2012 with the goal to "perform rehabilitation of the river bed creating beautified and healthier environment for the inhabitants," was not completely successful, as it did not pay attention to remediation of mine tailings of Kishnica and Hajvalia-Badovci. Therefore, further monitoring of water and possibly sediments of Graçanica River is advised, as well as performing of remediation of Kishnica and Badovci mine tailing dams.

\section{Competing Interests}

The authors declare that there is no conflict of interests regarding the publication of this paper; the mentioned received funding in Acknowledgments did not lead to any conflict of interests regarding the publication of this manuscript; also there is no other possible conflict of interests in the manuscript.

\section{Acknowledgments}

The study was financially supported by University of Prishtina. Measurements were performed at laboratory "Agrovet" in Fushë Kosova and at laboratory of Chemistry Department, Faculty of Science in Prishtina. Special thanks go to the collaborators of the Department of Chemistry in Prishtina, Dr. Valdet Pruthi.

\section{References}

[1] Lenntech Water Treatment and Air Purification, Water treatment. Lenntech, Rotterdamseweg, Netherlands, http://www .lenntech.com/applications/drinking/drinking_water.htm.

[2] A. S. Mildvan, "Metal in enzymes catalysis," in The Enzymes, D. D. Boyer, Ed., vol. 11, pp. 445-536, Academic Press, London, UK, 1970.

[3] M. Esshaimi, N. Ouazzani, M. Avila, G. Perez, M. Valiente, and L. Mandi, "Heavy metal contamination of soils and water resources kettara abandoned mine," American Journal of Environmental Sciences, vol. 8, no. 3, pp. 253-261, 2012.

[4] H. El Khalil, O. El Hamiani, G. Bitton, N. Ouazzani, and A. Boularbah, "Heavy metal contamination from mining sites in South Morocco: monitoring metal content and toxicity of soil runoff and groundwater," Environmental Monitoring and Assessment, vol. 136, no. 1, pp. 147-160, 2008.

[5] R. Lăcătuşu, G. Cîtu, J. Aston, M. Lungu, and A. R. Lăcătuşu, "Heavy metals soil pollution state in relation to potential future mining activities in the Roşia Montană area," Carpathian Journal of Earth and Environmental Sciences, vol. 4, no. 2, pp. 39-50, 2009.

[6] P. Higueras, R. Oyarzun, J. Oyarzún, H. Maturana, J. Lillo, and D. Morata, "Environmental assessment of copper-goldmercury mining in the Andacollo and Punitaqui districts, northern Chile," Applied Geochemistry, vol. 19, no. 11, pp. 1855$1864,2004$.

[7] L. Zhai, X. Liao, T. Chen et al., "Regional assessment of cadmium pollution in agricultural lands and the potential health risk related to intensive mining activities: A Case Study in Chenzhou City, China," Journal of Environmental Sciences, vol. 20, no. 6, pp. 696-703, 2008.

[8] F. Habashi, "Environmental issues in the metallurgical Industry progress and problems," in Environmental Issues and Waste Management in Energy and Mineral Production, pp. 1143-1153, Balkama, Rotherdam, UK, 1992.

[9] D. Peplow, Environmental Impacts of Mining in Eastern Washington, Center for Water and Watershed Studies Fact Sheet, University of Washington, Seattle, Wash, USA, 1992.

[10] A. Kebata-Pendias and H. Pendias, Trace Elements in Soils and Plants, CRC Press, Boca Raton, Fla, USA, 1986. 
[11] S. Pandey and S. Tiwari, "Physico-chemical analysis of ground water of selected area of Ghazipur city. A case study," Nature and Science, vol. 7, no. 1, pp. 17-20, 2009.

[12] S. J. Altman and R. R. Parizek, "Dilution of nonpoint-source nitrate in groundwater," Journal of Environmental Quality, vol. 24, no. 4, pp. 707-718, 1995.

[13] A. Jinwal and A. Dixit, "Pre- and post-monsoon variation in physico-chemical characteristics in groundwater quality of Bhopal 'The City of Lakes' India,' Asian Journal of Experimental Sciences, vol. 22, no. 3, pp. 311-316, 2008.

[14] L. Järup, "Hazards of heavy metal contamination," British Medical Bulletin, vol. 68, pp. 167-182, 2003.

[15] M. R. Bruins, S. Kapil, and F. W. Oehme, "Microbial resistance to metals in the environment," Ecotoxicology and Environmental Safety, vol. 45, no. 3, pp. 198-207, 2000.

[16] UNDP, "Industrial waste management for Trepça enterprise," International Conference Report, UNDP, Mitrovica, Kosova, 2011.

[17] M. Elshemy and G. Meon, "Climate change impacts on water quality indices of the southern part of Aswan High Dam reservoir, Lake Nubia," in Proceedings of the 15th International Water Technology Conference, p. 17, Alexandria, Egypt, 2011.

[18] A. Astel, M. Biziuk, A. Przyjazny, and J. Namieśnik, "Chemometrics in monitoring spatial and temporal variations in drinking water quality," Water Research, vol. 40, no. 8, pp. 1706-1716, 2006.

[19] V. Simeonov, J. A. Stratis, C. Samara et al., "Assessment of the surface water quality in Northern Greece," Water Research, vol. 37, no. 17, pp. 4119-4124, 2003.

[20] K. P. Singh, A. Malik, V. K. Singh, D. Mohan, and S. Sinha, "Chemometric analysis of groundwater quality data of alluvial aquifer of Gangetic plain, North India," Analytica Chimica Acta, vol. 550, no. 1-2, pp. 82-91, 2005.

[21] S. Shrestha and F. Kazama, "Assessment of surface water quality using multivariate statistical techniques: a case study of the Fuji river basin, Japan," Environmental Modelling and Software, vol. 22, no. 4, pp. 464-475, 2007.

[22] F. Gashi, S. Francikovic-Bilinski, and H. Bilinski, "Analysis of sediments of the four main rivers (Drini i bardhë, Morava e Binces, Lepenc and Sitnica) in Kosovo," Fresenius Environmental Bulletin, vol. 18, pp. 1462-1471, 2009.

[23] F. Gashi, S. Franciskovic-Bilinski, H. Bilinski, N. Troni, M. Bacaj, and F. Jusuf, "Establishing of monitoring network on Kosovo Rivers: preliminary measurements on the four main rivers (Drini i Bardhë, Morava e Binqës, Lepenc and Sitnica)," Environmental Monitoring and Assessment, vol. 175, no. 1-4, pp. 279-289, 2011.

[24] F. Gashi, N. Troni, F. Faiku et al., "Chemical and statistical analyses of elements in river water of Morava e Binçës," American Journal of Environmental Sciences, vol. 9, no. 2, pp. 142-155, 2013.

[25] F. Gashi, N. Troni, R. Hoti et al., "Chemical determination of some elements in water of Sitnica River (Kosovo) by ICP-MS technique," Fresenius Environmental Bulletin, vol. 23, no. 1, pp. 91-97, 2014

[26] F. Gashi, S. Frančišković-Bilinski, H. Bilinski, and L. Kika, "Assessment of the effects of urban and industrial development on water and sediment quality of the Drenica River in Kosovo," Environmental Earth Sciences, vol. 75, article 801, 2016.

[27] F. Gashi, S. Frančišković-Bilinski, H. Bilinski, A. Haziri, and S. Gashi, "Assessing the trace element content in water samples from Badovci Lake (Kosovo) using inductively coupled plasmamass spectrometry analysis," Arabian Journal of Geosciences, vol. 9, no. 6, 2016.

[28] Ministry of Environment and Spatial Planning and Kosovo Environmental Protection Agency, Report Environmental Hotspots in Kosovo, 2011.

[29] Technical University of Crete, Strategic Plan for the Prevention of Regional Water Resources Contamination from Mining and Metallurgical Industries in Western Balkan Countries, Technical University of Crete, Chania, Greece, 2007.

[30] WHO, Guideline for Drinking Water Quality. Volume 1: Recommendations, WHO, Geneva, Switzerland, 3rd edition, 2004.

[31] WHO, "Chemical safety of drinking-water: assessing priorities for risk management," International Journal of Environmental Studies, vol. 69, no. 6, p. 1001, 2012.

[32] US EPA, Drinking Water Contaminants. Safe Water, 2006.

[33] APHA, Standard Methods for the Examination of Water and Waste Water, American Public Health Association, New York, NY, USA, 20th edition, 1998.

[34] A. Baba, A. Kaya, and Y. K. Birsoy, "The effect of Yatagan thermal power plant (Mugla, Turkey) on the quality of surface and ground waters," Water, Air, and Soil Pollution, vol. 149, no. 1-4, pp. 93-111, 2003.

[35] B. Dalmacija, Water Quality Control in towards of Quality Management, Text Book, 2000.

[36] StatSoft, "Statistica, data analysis software system," version 6, 2001.

[37] S. Frančišković-Bilinski, V. Cuculić, H. Bilinski, H. Häusler, and P. Stadler, "Geochemical and stable isotopic variability within two rivers rising under the same mountain, but belonging to two distant watersheds," Chemie der Erde-Geochemistry, vol. 73, no. 3, pp. 293-308, 2013.

[38] J. W. Tukey, Exploratory Data Analysis, Addison-Wesley, Reading, Mass, USA, 17th edition, 1977.

[39] J. E. Fergusson, The Heavy Elements: Chemistry, Environmental Impact and Health Effects, Pergamon Press, Oxford, UK, 1st edition, 1990.

[40] E. Kovács, T. János, S. Frančišković-Bilinski, D. Omanović, H. Bilinski, and I. Pižeta, "Geochemical study of surface water and sediment at the abandoned pb-zn mining site at Gyöngyösoroszi, Hungary," Fresenius Environmental Bulletin, vol. 21, no. 5, pp. 1212-1218, 2012. 

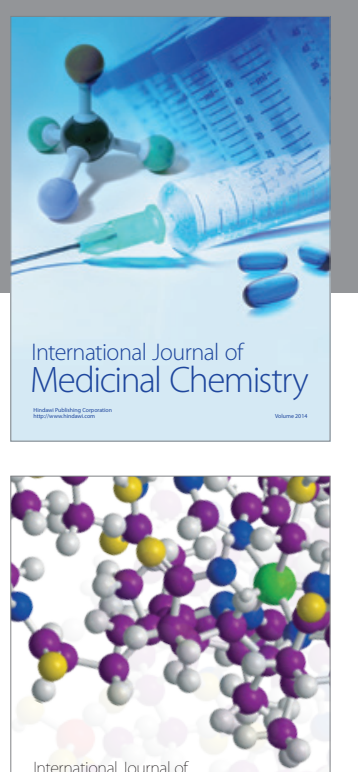

Carbohydrate Chemistry

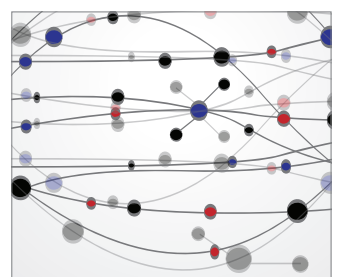

The Scientific World Journal
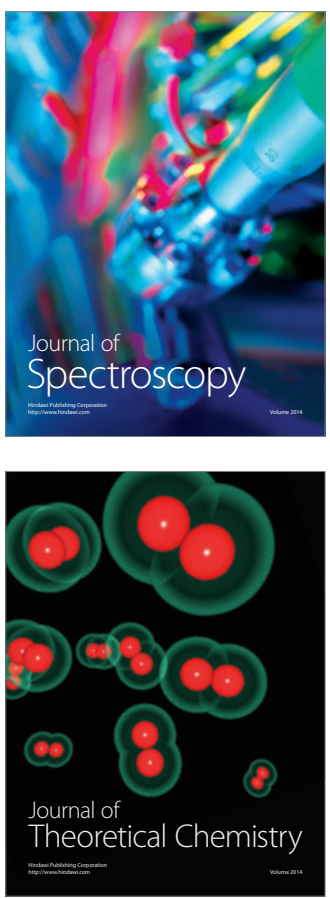
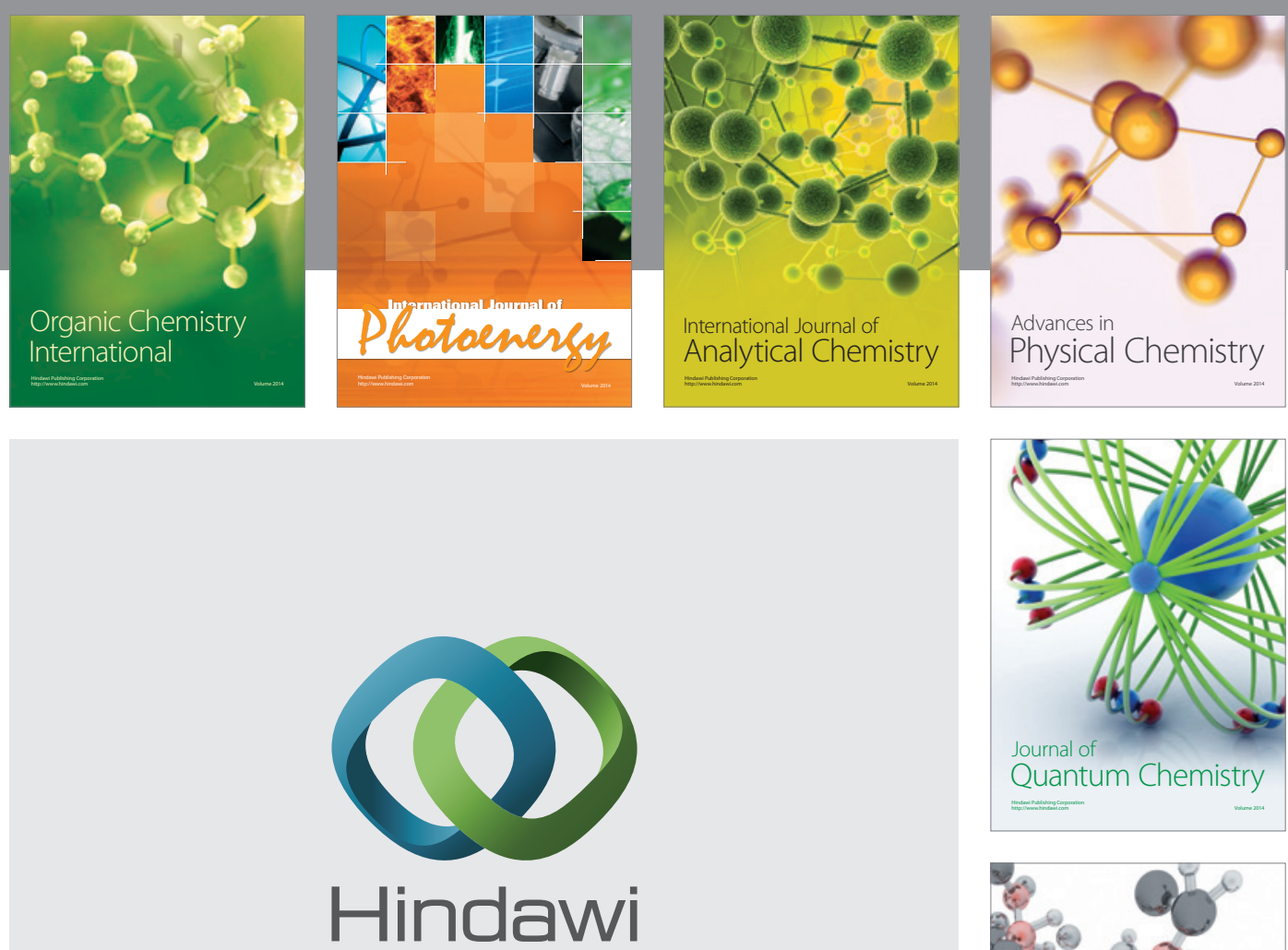

Submit your manuscripts at

https://www.hindawi.com

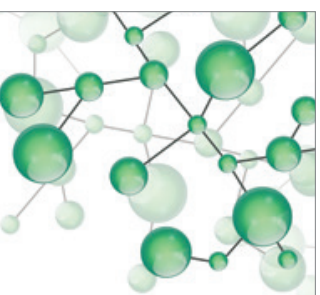

International Journal of

Inorganic Chemistry
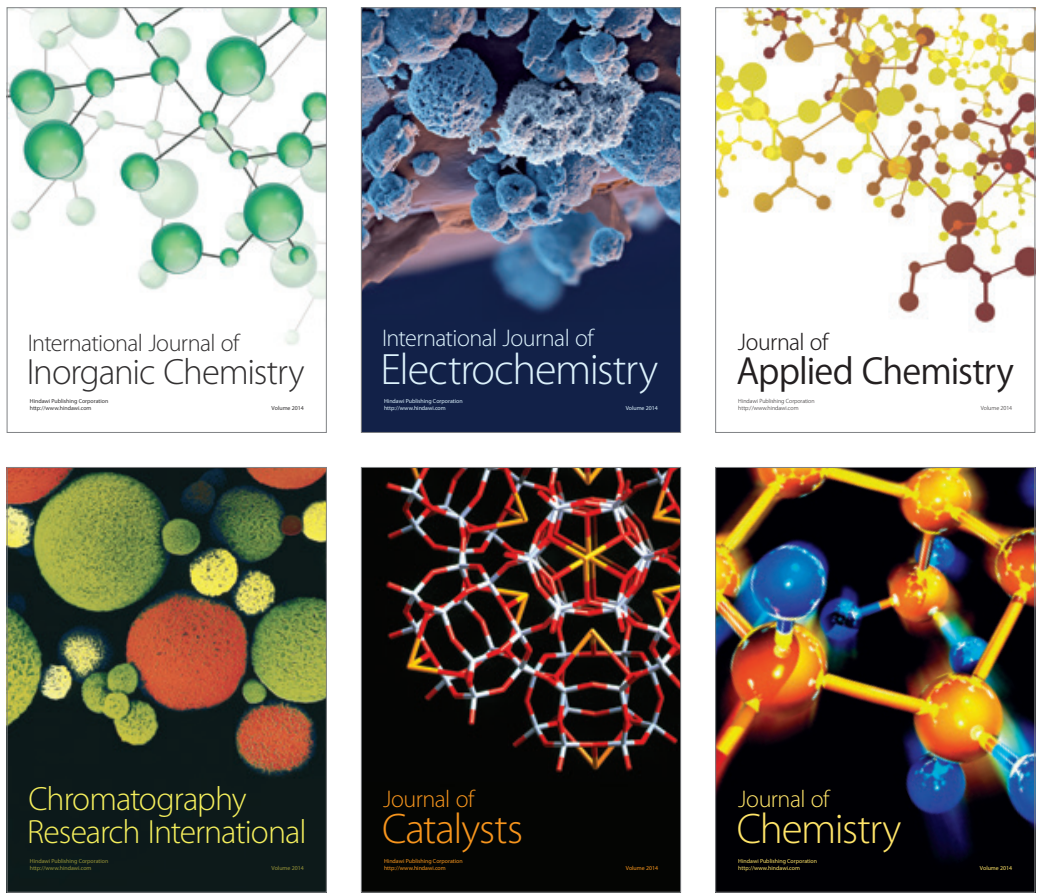

Journal of

Applied Chemistry
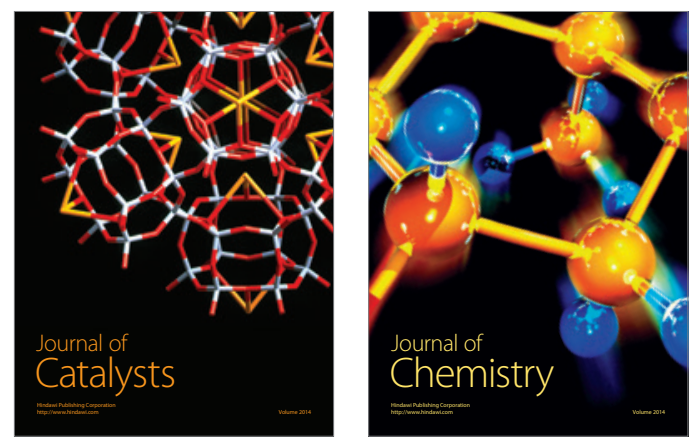
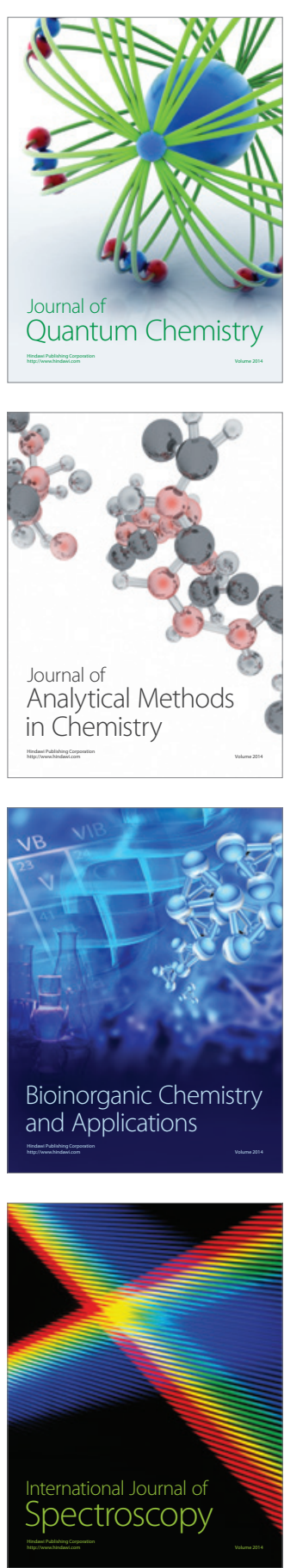